\title{
'PARLIAMENTARISATION' OF THE CFSP: WISHFUL THINKING OR A RATIONAL CHOICE?
}

\author{
Oleksandr Moskalenko*
}

\begin{abstract}
Summary: The paper provides an insight into the institutional system of EU external relations, focusing on the role of the European Parliament. It argues that the current intergovernmental set-up of the CFSP is one of the major reasons for EU international under-performance. Against this background, the paper discusses the potential benefits of the 'parlimentarisation' of this policy area, implying deeper Parliamentary involvement in the entire policy cycle (preparation, formation, supervision).

The paper argues that the parliamentarisation of the CFSP would provide a practical and comprehensive solution to a number of diverse problems that the EU has encountered recently. Besides reinforcement of the EU foundations by connecting the CFSP with a grand theory of democratic legitimacy, this process would enhance the transparency, coherence and effectiveness of the policy formation process as well as the accountability of the EU executives involved in this policy area.
\end{abstract}

\section{Introduction}

Relations between international organisations and parliaments have never been simple. ${ }^{1}$ In this sense, the European Union (EU) is no different. But if a political system works successfully and effectively these relations are not usually at the top of the agenda. However, the post-Lisbon EU foreign policy can hardly be called a success, with the European Neighbourhood Policy (ENP) being an example of rather the opposite. The political turbulence and further radicalisation in Northern Africa in the aftermath of the 'Arab Spring' as well as the armed conflicts in Ukraine and Syria morphed the EU neighbourhood into something entirely different from the ENP's initial goal of prosperous neighbours sharing the common values of human rights, democracy and the rule of law.

Certainly, it was a combination of flaws that led to the frustrating result, requiring a closer look at all the components of the EU's external relations. From this perspective, the institutional framework must be no exception, especially in the context of it being a major target for the Lisbon transformations aimed at ensuring that Europe 'speaks with

PhD candidate, Faculty of Law, University of Turku, Finland.

1 J Wouters and K Raube, 'Europe's Common Security and Defence Policy: The Case for Inter-Parliamentary Scrutiny' (2012) Leuven Centre for Global Governance Studies Working Paper No 90, 8. 
one voice' in its international relations. This paper provides an insight into the institutional system of the EU external relations. It focuses on the current institutional role of the European Parliament (EP) within the Common Foreign and Security Policy (CFSP) and in the wider context of EU foreign policy. The article argues that the current intergovernmental set-up of the CFSP constrains both the formation and the implementation of EU foreign policy. In this context, the article discusses the potential benefits of 'parlimentarisation' of this policy area, by which is meant the EP's involvement in the entire policy cycle, including the preparation and formation of the CFSP as well as supervision of its implementation.

The paper argues that the parliamentarisation of the CFSP provides a practical and comprehensive option, which would facilitate progress of this policy area. In addition to considerably reinforcing the EU's foundations by embedding the CFSP into the wider context of the democratic legitimacy concept, parliamentarisation will enhance the transparency, coherence and effectiveness of the policy formation process as well as the accountability of the EU executives in this policy area. Its potential in terms of facilitating the formation of a genuinely common European policy based on the values declared by the Lisbon Treaty should also be stressed.

The paper consists of seven sections, including this introduction and a conclusion. Section 2 provides the background to the research with an analysis of specific features of EU foreign policy as well as the current legal framework of the EP's involvement in EU external relations. Section 3 studies the existing problems of the CFSP, which are mostly associated with the intergovernmental mode of its formation. Section 4 scrutinises the theoretical reasoning for the deeper involvement of the EP in the policy formation process, concentrating on the arguments of 'democratic deficit' and 'democratic legitimacy' whilst further elaborating this reasoning within the unique EU political environment. Section 5 moves from theory to practical challenges and analyses the potential that parliamentarisation possesses in terms of meeting them. Section 6 concentrates on the final stage of the policy cycle, providing a study of the potential benefits of an enhanced role for the EP in control over policy implementation, which includes the EP's relations with the High Representative of the Union for Foreign Affairs and Security Policy ('HR'), the European External Action Service (EEAS) and the heads of EU delegations.

\section{An asymmetric policy area and split competences.}

This section provides the background of the study by examining specific features of the EU as an international actor and the legal framework of the EP's involvement in its foreign policies. The overwhelming domi- 
nance of non-military tools is a paramount fact that shapes the entire structure of the EU's external relations. Despite previously raised hopes for a defence union, ${ }^{2}$ which were reasserted by the Lisbon Treaty, ${ }^{3}$ the formation of a common EU military force is currently more a political issue than a practical process, which reaffirms the ironic definition of the EU as 'economic giant, political gnome and military worm'. ${ }^{4}$ Thus, the concept of normative power supported by economic means of influence remains the major relevant explanatory model for the EU's impact on international politics. The first post-Lisbon HR Baroness Ashton stated that the EU 'cannot deploy gunboats or bombers'; instead, she stressed that the strength of the EU 'lies, paradoxically, in its inability to throw its weight around'. ${ }^{5}$ Indeed, that strength resides in trade, aid and development assistance, which have traditionally been at the core of the EU's ability to exert its influence and promote its values beyond the territory of its Member States. ${ }^{6}$ Therefore, instead of remaining an isolated policy, the CFSP should increasingly function as a policy that generates 'nexus decisions', which would underlie and consolidate other aspects of EU external relations. ${ }^{7}$ In this case, it will facilitate the development of synergy within EU foreign policy.

The Lisbon Treaty considerably enhanced the EP's position in most policies, yet not the CFSP. The new formula, which connected the consent right with the ordinary legislative procedure, ${ }^{8}$ covers 87 different policy areas. ${ }^{9}$ In this sense, trade, aid and development policies fall within the above-mentioned pattern of the strengthened EP role. Trade as the essential part of the Common Commercial Policy (CCP) falls within exclusive EU competence, ${ }^{10}$ while aid and development policies represent a specific case of competence division, with the Union having competence to conduct a common policy, although without preventing Member States

\footnotetext{
2 S Stavridis, "Why the "Militarising" of the European Union Is Strengthening the Concept of a "Civilian Power Europe"' (2001) European University Institute Working Paper 17. 
from exercising theirs. ${ }^{11}$ In the practical sense, all those policies are legislated in accordance with the ordinary legislative procedure. ${ }^{12}$ It should be stressed that the EP's role in these policies is not limited to its functions within the ordinary legislative procedure. For the CCP, the EP has become one of the key actors. ${ }^{13}$ Regarding assistance to third countries, the EP co-decides with the Council not only on the development cooperation instrument, but also on the financing aspects of all other instruments, ${ }^{14}$ thus enjoying an equal footing with the Council in terms of formal policymaking competences. ${ }^{15}$

In terms of international agreements within these policies, the procedure requires the EP's consent for all three cases. ${ }^{16}$ In the wider context, article 218 TFEU and the framework agreement of $2010^{17}$ confirmed a number of the EP's important rights, emphasising the general principle of equal treatment with the Council. ${ }^{18}$ These privileges, solidly based on the consent right and accompanied by its traditional agenda for foreign policies, made the EP an independent and powerful player in EU external relations. ${ }^{19}$ Moreover, the EP managed to use the post-Lisbon institutional uncertainty to successfully reinterpret its right to be informed' in international negotiations, and transformed it into a right to be 'involved', ${ }^{20}$ by providing ex-ante control as well. ${ }^{21}$ This raised its status to a position capable of steering the negotiators' agenda and controlling the negotiation process. ${ }^{22}$ In this way, the EP's resolutions play a twofold role: they indicate to the target country the EP's priorities and at the

11 Art 4 (4) TFEU.

12 Arts 207, 209, 212-214 TFEU.

13 Tiilikainen (n 9) 7.

14 In particular: Instrument for Pre-Accession Assistance; Instrument for European Neighbourhood Policy Initiative; Instrument contributing to Stability and Peace; Partnership Instrument; and European Instrument for Democracy and Human Rights.

15 P Bajtay, 'Shaping and Controlling Foreign Policy: Parliamentary Diplomacy and Oversight, and the Role of the European Parliament' (European Parliament, Think Tank 2015) 27 <www.europarl.europa.eu/thinktank/en/search.html?authors=25360> accessed 30 December 2016.

16 Art 218 (6 a (v)) TFEU.

17 Framework Agreement on relations between the European Parliament and the European Commission [2010] OJ L304/47.

18 ibid, point 9.

19 R Passos, 'The European Union's External Relations a Year after Lisbon: A First Evaluation from the European Parliament' in P Koutrakos (ed), The European Union's External Relations a Year after Lisbon (CLEER working paper No 3, 2011) 51.

20 Ariadna Ripoll Servent, 'The Role of the European Parliament in International Negotiations after Lisbon' (2014) 21(4) Journal of European Public Policy 568, 580.

${ }^{21}$ Lucia Serena Rossi 'A New Inter-Institutional Balance: Supranational vs Intergovernmental Method after the Lisbon Treaty' in The European Union after the Lisbon Treaty: Visions of Leading Policy-Makers, Academics and Journalists (European Union, DirectorateGeneral for Education and Culture 2011) 102.

22 Servent (n 20) 580. 
same time they are a means for the inter-institutional communication, thus providing 'a second mandate' for the Council and Commission. ${ }^{23}$ The academic literature provides a number of practical illustrations of this phenomenon. ${ }^{24}$ In particular, the case of the EU-South Korea Free Trade Agreement negotiations emphasised a new status of the EP as an 'emerging principal' in Principal-Agent relations with the Commission. ${ }^{25}$ Furthermore, this precedent-setting case revealed the growing potential of the EP 'to flex its muscles' in pushing the Commission for a number of important concessions in terms of both the essence of the treaty and the enhanced role of the EP during the negotiation procedure. ${ }^{26}$

In the de facto preserved 'second pillar' of the CFSP, which continues to be based on special rules, ${ }^{27}$ the EP's competences are much narrower. A number of informational rights are secured by article $36 \mathrm{TEU}$; however, the EP is formally excluded from the conclusion of international agreements ${ }^{28}$ as well as from the policy formation process. Those competences belong to the European Council and the Council, which shape the policies and adopt decisions as for the operational actions. ${ }^{29}$ Although the EP is to be informed of all European Council decisions, ${ }^{30}$ this right does not let it into the policy formation process, as the Council does not have any formal obligations should the EP adopt any document in this regard.

All obligations towards the EP lie with the HR, who is formally obliged 'to ensure that the views of the European Parliament are duly taken into consideration'. ${ }^{31}$ However, his/her major responsibility is to put the CFSP into effect. ${ }^{32}$ The practical aspects of the implementation of article 36 TEU are regulated by the Inter-Institutional Agreement of 2013, which established a specific format of regular political dialogue on the CFSP and quarterly reports on its implementation. ${ }^{33}$ Nonetheless, with the EP

\footnotetext{
23 Passos (19) 55.

24 S Stavridis and D Irrera (eds), The European Parliament and its International Relations (Routledge 2015).

25 M Elsig and C Dupont, 'European Union Meets South Korea: Bureaucratic Interests, Exporter Discrimination and the Negotiations of Trade Agreements' (2012) 50(3) Journal of Common Market Studies 492, 502.

26 ibid 498-502.

27 W Wessels and F Bopp, 'The Institutional Architecture of CFSP after the Lisbon Treaty: Constitutional Breakthrough or Challenges Ahead?' (2008) CEPS Challenge Research Paper No 10, 2 <http://aei.pitt.edu/9403/> accessed 30 December 2016.

28 Art 218 (6) TFEU.

29 Art 22 (1), 26, 28 (1), 29 TEU.

30 Art $15(6 \mathrm{~d})$ TEU.

31 Art 36 TEU.

32 Art 22 (1) TEU.

33 Section E of Part II of the Inter-institutional Agreement of 2 December 2013 between the European Parliament, the Council and the Commission on budgetary discipline, on cooperation in budgetary matters and on sound financial management [2013] OJ C373/01.
} 
remaining formally excluded from the CFSP formation process as well as from the adoption of instruments, ${ }^{34}$ it is often called an 'ex post facto information receiver'. ${ }^{35}$

The remaining split in EU foreign policy is illogical from the perspective of the interconnection between the CFSP and other areas of foreign policy mentioned above, as well as the blurred borderlines between them. Further, any form of external action can be brought within the term 'foreign and security policy', which develops into the problem of overlapping competences. ${ }^{36}$ Against this background, the asymmetry of the EP's competences is developing into a separate institutional problem. The practical example of the EU's 'targeted sanctions'37 emphasised that the difference in procedures between the CFSP and other policy areas, as well as the difference in the EP's role in these procedures, increases the potential for inter-institutional conflicts as the boundaries between the CFSP and other aspects of EU foreign policy are blurred. ${ }^{38}$ In the case referred to above, the margin between the CFSP and the Area of Freedom, Security and Justice (AFSJ) was rather vague. Thus, the EP used the opportunity and contested the choice of the legal basis for the documents in question, arguing in favour of article 75 TFEU since it provided for the application of the ordinary legislative procedure instead of the mere informing of the EP by the Council as foreseen by the other option. ${ }^{39}$

In a wider context, the split in the EP's external competences remains one of the reasons that the EU is often referred to as "punching below its global weight ${ }^{30}$ in its relations with third countries, which implies a significant space for improvement in this policy area. Below, this paper deals with a number of institutional reasons for this phenomenon. Further, the paper also studies the benefits of CFSP parliamentarisation, reaffirming the general argument here concerning the potential of this process for reinforcing the EU's international performance.

\footnotetext{
34 Art 25 TEU.

35 S Stavridis, "The CFSP/ESDP, Parliamentary Accountability, and the "Future of Europe" Convention Debate' (2003) Working Paper No 42, 3.

36 J Schmidt, 'The High Representative, the President and the Commission-Competing Players in the EU's External Relations: The Case of Crisis Management' in PJ Cardwell (ed), EU External Relations Law and Policy in the Post-Lisbon Era (TMC Asser Press 2012) 173175.

37 D Cortright and others, 'Targeted Financial Sanctions: Smart Sanctions That Do Work' in D Cortright and G Lopez (eds), Smart Sanctions. Targeting Economic Statecraft (Rowman and Littlefield 2002).

38 P van Elsuwege, "The Adoption of "Targeted Sanctions" and the Potential for Inter-institutional Litigation after Lisbon' (2011) 7(4) Journal of Contemporary European Research.

39 Art 215 (2) TFEU.

$40 \operatorname{Mix}(\mathrm{n} 6) 2$.
} 


\section{What is the problem?}

This section studies the structural flaws of the CFSP formation process, arguing that the existing framework undermines the development of EU foreign policy. For decades, EU foreign policy has been associated with 'a lack of leadership, continuity, consistency and diplomatic resources'. ${ }^{41}$ One of the major goals of the Lisbon reforms was to rectify those defects. However, the post-Lisbon CFSP 'intergovernmental construction' is still associated with a lack of strategic coherence and a lack of 'a spirit of unity, coherence and efficiency', subsequently leading to weak international EU actorness. ${ }^{42}$ Supporting this claim, the paper submits that the intergovernmental policy formation mode prevents the formation of a consistent and coherent European foreign policy. Defining the intergovernmental mode, the article refers to a combination of features, including the national veto right, the dominance of national executives and the formal exclusion of the EP from the process.

The Member States' veto right ${ }^{43}$ is one of the important features that determines the entire framework of the CFSP. Certainly, it is one of the major reasons for the national-based policy formation mode, which, however, meets the intention of the Member States (particularly the large and powerful ones) of having their own agendas for foreign policy. They have little intention of letting the HR assume an automatic lead on policy issues, particularly sensitive ones, thus preventing him/her from creating his/her own political direction, especially if it is proactive and robust. ${ }^{44}$ Therefore, EU foreign policy is often associated with the leaders of the EU's largest countries: Germany, France and the UK. An illustration of this argument is the rather dubious situation of Egypt in the aftermath of the 'Arab spring' when the new Egyptian government declared that they were 'too busy' to receive the $\mathrm{HR} ;{ }^{45}$ however, about two weeks later they welcomed the UK Prime Minister. ${ }^{46}$

\footnotetext{
41 J Paul, 'EU Foreign Policy after Lisbon. Will the New High Representative and the External Action Service Make a Difference?' (2008) Center for Applied Policy Research (CAP) Policy Analysis No 2, 8 <http:/ /edoc.vifapol.de/opus/volltexte/2009/785/pdf/CAP_Policy_ Analysis_2008_02.pdf $>$ accessed 30 December 2016.

42 L Corduneanu, 'CFSP - Vacillating Between Supranationalism and Intergovernmentalism?’ (2014) CES Working Papers 6(1), 58 < http://journals.indexcopernicus.com/issue. php?id=9384\&id_issue=873835> accessed 30 December 2016 .

43 Art 31 (1) TEU.

44 J Howorth, 'Catherine Ashton's Five-Year Term: A Difficult Assessment' (2014) 3 Les Cahiers européens de Sciences 20 <www.cee.sciences-po.fr/en/publications/les-cahierseuropeens/2014/doc/1142/raw> accessed 30 December 2016.

45 'Don't Visit Us for the Moment, Egypt Tells EU's Ashton' M\&G News (February 2011).

46 N Gros-Verheyde, 'La "course du Caire", nouveau jeu européen. Ou comment griller la politesse à Lady Ashton' Bruxelles 2 (21 February 2011).
} 
Thus, the current national-based mode of CFSP formation, built around the national veto right, constitutes 'a principal obstacle to a more proactive EU foreign policy ${ }^{47}$ for at least two reasons. First of all, it may prevent the development of any policy at all, ${ }^{48}$ which is quite often the case. Moreover, instead of developing a genuinely all-European policy, this mode implies the coordination and unification of policies generated in national capitals, with the HR being burdened with this duty. So, she/ he is forced to play the role of mediator shuttling between the capitals and negotiating compromises, being 'caught somewhere between a responsibility to coordinate and a responsibility to exercise some measure of leadership'. ${ }^{49}$ However, the nature of such a coordination process is certainly different from genuine policy formation. In many ways it is similar to consensus-building, which is dealt with below. Furthermore, the absence of strategic policies can hardly be compensated for by any reactive actions, which is especially true for rapidly developing crises.

For practical illustration of the last point, one needs look no further than the crises in the EU neighbourhood. During the Arab Spring, the critical need for the HR to obtain unanimous and full backing from the Member States for her actions ${ }^{50}$ and their inability to promptly come to common accords made the EU look rather helpless against the rapidly deteriorating situation. A rather similar situation developed in Ukraine after the outrage of the 'Revolution of Dignity'. ${ }^{51}$ The HR's visits to Kiev were not well coordinated with either the work being done by the Commission or with the parallel visit of the EU troika of Laurent Fabius, Frank-Walter Steinmeier and Radek Sikorski. ${ }^{52}$ Thus, it was the cacophony emanating from Europe that led the US Under-Secretary of State, Victoria Nuland, to utter her famous leaked expletive. ${ }^{53}$

The second reason is the fact that the national-based policy formation mode facilitates the fragmentation of EU foreign policies. In the absence of any common policy, the Member States certainly have an alternative modus operandi, as they are capable of both independent action and action within a group. These options not only create additional pressure on the policy formation process, but also marginalise the CFSP to extraordinary cases of common threats, thus making this policy the 'last resort' option against the divergence of national perspectives and priorities, with the Iraq war of 2003 and the Kosovo case being well-

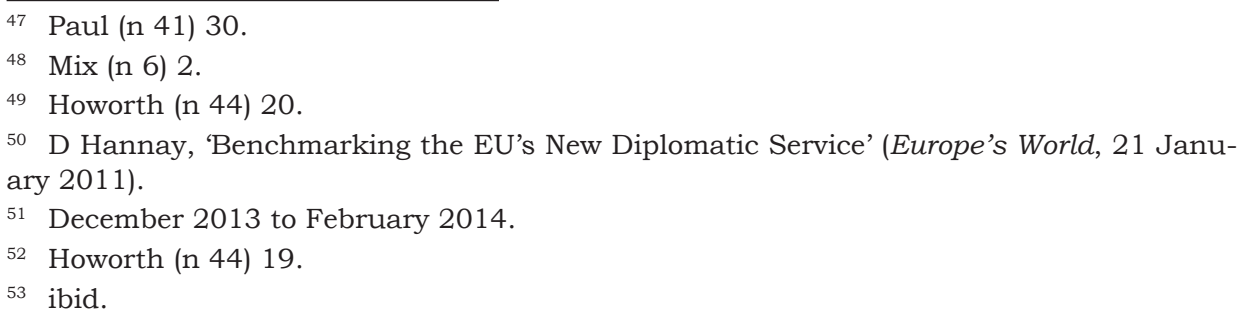


known illustrations. ${ }^{54}$ Furthermore, the current mode of policy formation 'almost inevitably' leads to the lack of 'strategic thrust or "heroic" objectives'. ${ }^{55}$ The diversity of national political interests varies so greatly that a consensus often requires extraordinary efforts. Moreover, consensus is a matter of degree, 'varying in depth from an agreement on general policy parameters and objectives down to specific policy details'. ${ }^{56}$ Against this background, the logic of consensus-building implies the lowest common policy denominators, as they are easiest to reach within a limited timeframe. However, this reality suggests two consequences. The first is the constant coordination process, and the second is the 'thorny path' from one 'lowest common policy denominator' to another. Both consequences are incompatible with the development of long-term strategies. Neither can consistency of common policy be reasonably expected under the circumstances. Ultimately, the process of constant compromises, coordination, matching and concords between 28 different positions raises such basic questions as what the policy actually is and who developed it.

\section{Why the European Parliament?}

This section focuses on providing the theoretical reasoning behind the idea of CFSP parliamentarisation. It briefly summarises the major arguments in the academic debate and further elaborates them within the specific political environment of the EU. In this sense, the limited participation of national legislatures in the foreign policy of the Member States is a 'false friend' for comparison, as the EU 'no-state' status leads to a number of tricky consequences which cannot be ignored without missing the devil in the details. But first, the theory.

Democracy and legitimacy: these two concepts cover most of the theoretical arguments for parliaments to participate in making public policies and creating compulsory rules. ${ }^{57}$ From Ancient Greece to contemporary post-modern societies, these concepts continue to shape the architecture of power. It is no surprise that the EP has often utilised this type of argument for its 'egoistic' institutional purposes of appealing for more competences. Although this argumentation has been referred to as 'democratic blackmailing', ${ }^{58}$ it still remains valid as it appeals to the basic

\footnotetext{
$54 \operatorname{Mix}(\mathrm{n} 6) 8$.

55 J Howorth and A Menon, 'Still Not Pushing Back: Why the European Union Is Not Balancing the United States' (2009) 53(5) Journal of Conflict Resolution 727.

56 Mix (n 6) 9.

57 J Mittag and W Wessels, The Parliamentary Dimension of CFSP/ESDP. Options for the European Convention' (2002) Study submitted for the European Parliament DirectorateGeneral for Research under Contract No IV/2002/01/01 Final report, 18.

58 D Thym, 'Beyond Parliament's Reach? The Role of the European Parliament in the CFSP' (2006) 11(1) European Foreign Affairs Review109, 115-117.
} 
concepts at the core of 'Western civilization' as a philosophical category. Contained in the works of Enlightenment philosophers such as Hobbs, Montesquieu, and Locke, as well as the US Founding Fathers, ${ }^{59}$ these concepts initiated the modern type of state, and still remain its cornerstone. The same theoretical tradition was continued by the social philosophers of the post-modern era, with J Habermas being one of the most famous and most consistent promoters of the idea that it is democracy which lies at the core of legitimacy. ${ }^{60}$ Although they have developed throughout recent centuries due to the evolution of Western societies, the concepts of democracy and legitimacy have preserved their clear and simple logics, as well as their close interconnection: 'in liberal democracies there can be no legitimacy without democracy and there can be no democracy without representation'. ${ }^{61} \mathrm{~J}$ Rawls echoes this understanding, referring to the exceptional role of these concepts and stressing that democratic legitimacy is the only form of legitimacy available to liberal societies. ${ }^{62}$

For decades the concepts of democracy and legitimacy have been at the core of the European discourse. ${ }^{63}$ The debate has had two separate focuses on what are termed 'input' and 'output' legitimacy. Defining their difference, C Sharman stressed that both forms express public assessment of the worth of an institution; however, 'input legitimacy is a matter of the design of the institution while output legitimacy must be earned by the institution's performance'. ${ }^{64}$ It was the extensive post-Maastricht 'democratic deficit' debate ${ }^{65}$ that transferred the issue of EU democratisation into one of the priorities for the Lisbon reforms. The 'input legitimacy' debate made the EP one of its major focuses as it was considered to be a source of legitimacy for the EU institutional system. ${ }^{66}$ Furthermore, the EP was considered to be the key EU institution that would lead to a new democratic quality for the Union, thus turning the entire EU system

\footnotetext{
59 A Hamilton, J Madison and J Jay, The Federalist Papers (Palgrave Macmillan 1961).

60 J Habermas, 'Die Postnationale Konstellation und die Zukunft der Demokratie' in J Habermas (ed), Die Postnationale Konstellation. Politische Essays (Suhrkamp Verlag 1998).

61 C Lord, The Political Theory and Practice of Parliamentary Participation in the Common Security and Defence Policy (2011) 18(8) Journal of European Public Policy 1133, 1147.

62 J Rawls, Political Liberalism (Columbia University Press 1993) 38.

63 T Banchoff and M Smith, 'Introduction: Conceptualizing Legitimacy in a Contested Polity' in T Banchoff and M Smith (eds), Legitimacy and the European Union (Routledge 1999); and A Moravcsik, 'Reassessing Legitimacy in the European Union' (2002) 4 Journal of Common Market Studies 603.

64 C Sharman, 'Political Legitimacy for an Appointed Senate' (2008) 14(11) IRPP Choices 2, 6-7.

65 See for example, Frank Decker, 'Governance beyond the Nation State. Reflections on the Democratic Deficit of the European Union (2002) 9(2) Journal of European Public Policy 256; Giandomenico Majone, 'Europe's “Democratic Deficit”: The Question of Standards' (1998) 4(1) European Law Journal 5.

66 C Strøby-Jensen, 'Neo-functionalism' in M Cini and N Pérez-Solórzano Borragán, European Union Politics (OUP 2010) 75-77.
} 
into an 'ordinary' democratic system. ${ }^{67}$ These ideas underlie the Lisbon parlimentarisation of the EU institutional system, thus reflecting the interconnection between democratic legitimacy at the conceptual level and the increase in the EP's institutional influence. ${ }^{68}$

The general nature of these concepts is evident. $\mathrm{N}$ Lalone presents the argument that 'democratic foundation' reasoning would apply equally to the CFSP, ${ }^{69}$ as no specific public policy has an exceptional status, at least in theory. However, traditionally it has been foreign policy that enjoys special status as the realm of executives inter alia in terms of policy making. ${ }^{70}$ Nonetheless, this practice developed at the national level requires additional examination in terms of both reasoning and consequences. Traditionally, references to secrecy and limited EP expertise have been major arguments against a greater role for the EP in the CFSP. Below, this section discusses each of these points.

The argument regarding the EP's limited expertise ${ }^{71}$ can hardly be viewed as sufficient. First of all, the role that the EP is supposed to play in the policy formation process certainly differs from that of highly specialised executive technocrats. This role is to form a bridge from the area of specialised expertise to public debate with further reference to democratic legitimacy. ${ }^{72}$ In this sense, the experience that the EP has in public debate and political dialogue construction ${ }^{73}$ should be stressed separately. Furthermore, its experience in sensitive international situations ${ }^{74}$ as well as in the policy formation process would certainly be able to provide benefits to the CFSP as well. Another fact is that the EP has already been extensively involved in the EU foreign policy formation process. Although this was not the CFSP but adjoining areas of trade, aid and development, this fact already implies that the EP is no novice when it comes to EU external relations. The figures speak for themselves. In the course of the 7th legislative term (2009-2014) the EP's Committee on Foreign Affairs

67 Mittag and Wessels (n 57) 12.

68 I Bache, S Bulmer and S George, Politics in the European Union (3rd edn, OUP 2011) 2627.

69 N Lalone, 'Accountability in the EU's Common Foreign and Security Policy: Lessons from the Common Commercial Policy' in Anna Herranz and Esther Barbé (eds), The Role of Parliaments in European Foreign Policy: Debating on Accountability and Legitimacy (Oficina d’informació del Parlament Europeu 2005) 9.

70 D Thym, Parlamentsfreier Raum? Die Rolle des Europäischen Parlaments in der Gemeinsamen Außenund Sicherheitspolitik (2005) 13 <www.whi-berlin.de/EPinderGASP.htm> accessed 30 December 2016.

71 Lalone (n 69) 12.

72 ibid 40.

73 G Hamilton, 'Parliamentary Diplomacy' (2010) (Adopted by the Committee of Senior Members of the Senate of the States General, 16 November 2010) 4.

74 F Weisglas and G De Boer, 'Parliamentary Diplomacy' (2007) 2 The Hague Journal of Diplomacy 93, 96. 
(AFET) adopted 104 reports, 46 own initiative reports and 99 opinions. ${ }^{75}$ Moreover, AFET members are not only deeply involved in EU external relations, but also have access to the classified information necessary. ${ }^{76}$

Given the common understanding that foreign policy is a policy of a strategic nature, whereby choices of values and strategies are made with long-lasting implications, ${ }^{77}$ it appears paradoxical to deploy arguments of secrecy, confidentiality and flexibility against the EP's participation. ${ }^{78}$ At the current level of international relations, the phrase 'secret strategy' sounds like an oxymoron, reviving memories of the secret pacts of previous centuries, which divided the world into 'spheres of influence'. ${ }^{79}$ Is it a pattern that the EU follows? Certainly not. Furthermore, there is growing discrepancy between the development of modern polities and the idea that strategic decisions can be made outside public debate. It is the historic perspective that is emphasised by Lord, who connects the secrecy and flexibility arguments with two of Locke's observations concerning the unpredictable nature of possible dangers and the appeal for a wider margin of freedom for the government to adequately meet these challenges. ${ }^{80}$ However, he is rather sceptical about the validity of these arguments. ${ }^{81}$

One should also stress the growing divergence between the secrecy argument and the contemporary requirements of democratic rule. Despite the fact that the Lisbon Treaty has not provided a clear formal solution in terms of 'the tension between effective international security coordination and democratic accountability', 82 it nonetheless marked the next level of EU development with article 10 TEU, ${ }^{83}$ recognising it as a representative democracy, although some scholars emphasise its sui generis nature. ${ }^{84}$ From this perspective, the principles of democratic rule are formulated as

\footnotetext{
75 Bajtay (n 15) 3.

76 Inter-institutional Agreement between the European Parliament and the Council concerning the forwarding to and handling by the European Parliament of classified information held by the Council on matters other than those in the area of the Common Foreign and Security Policy of 12 March 2014.

77 Bajtay (n 15) 23, 39.

78 J Böcker, Demokratiedefizit der Sicherheits- und Verteidigungspolitik der EU? Analyse des deutschen, britischen und Europäischen Parlaments (Nomos 2012) 23 <www.nomosshop.de/14338> accessed 30 December 2016; D Peters, W Wagner and C Glahn, 'Parliamentary Control of Military Missions: The Case of the EU NAVFOR Atalanta' (2011) RECON Online Working Paper 2011/24.

79 USSR-Germany (Molotov-Ribbentrop) pact of 1939, for example.

80 Lord (n 61) 146.

81 ibid.

82 W Wagner, Demokratische Kontrolle internationalisierter Sicherheitspolitik: Demokratiedefizite bei Militäreinsätzen und in der europäischen Politik innerer Sicherheit (Nomos 2010) 187.

83 Art 10 (1) TEU.

84 P Magnette and K Nikolaidis, 'The European Union's Democratic Agenda' in M Telo (ed), The European Union and Global Governance (Routledge 2009) 54.
} 
a legal obligation of a higher level. Furthermore, the contemporary development of post-modern societies has put greater pressure on politicians, who are expected to act within democratic arrangements. ${ }^{85}$ Thus, compliance with minimal democratic standards ${ }^{86}$ has developed into a political imperative. It is especially true for the EU, with its vulnerable 'no-state' status, continuous legitimacy deficit debate and dependence on both European public opinion and the policies of its Member States.

From the experience of foreign policy formation at the national level, two observations must be noted. The first is the fact that policy is made by a strong political player, which is the government. Although the level of its internal cohesion may vary depending upon the principles of its formation in a particular country, it is still one government, which shares a certain level of internal unity, as well as a common political destiny as a government. For comparison, reference is often made to the USA and the UK, which also illustrate the claims that this paper submits. In both cases the governments play a central role in the countries' political establishment, and they are strong players, possessing both influence and resources. The second observation is the existence of rather blurred borderlines between making foreign policy and implementing it, as the same people are involved at both levels. From this perspective, the references to secrecy, efficiency and flexibility make sense as they refer to the implementation stage, which indeed requires them.

In the discussion of the consequences for the EU of the special status of foreign policy at the national level of Member States, three should be stressed separately. First of all, the limited parliamentary scrutiny over foreign policy at the level of the Member States has substantiated the 'democracy deficit' debate, developing it into the 'double democracy deficit' argument specifically for the CFSP. ${ }^{87}$ This argument implies that the involvement of the EP in this policy area is crucial from the perspective of the democratic legitimacy concept, as national parliaments do not fulfil this function.

The second consequence is the fact that the executive policy-making mode, which is typical for the national level, is not appropriate for the EU due to the fact that the Council and/or the European Council differ from national governments inasmuch as they are far more amorphous institutions. In this context, the question becomes who actually makes the CFSP? In reality, the vast majority of the 'spade work' is done by

85 U Krotz and R Maher, 'International Relations Theory and the Rise of European Foreign and Security Policy' (2014) 63(3) World Politics 548, 573.

86 J Bohman, 'Democratising the Transnational Polity: The European Union and the Presuppositions of Democracy' in EO Eriksen (ed), How to Reconstitute Democracy in Europe? (Proceedings from the RECON Opening Conference, RECON Report No 3, ARENA 2007).

87 Bajtay (n 15) 31. 
auxiliary institutions. ${ }^{88}$ At the same time, the institutions, which are formally entrusted with decision-making authorities, ${ }^{89}$ enjoy the format of 'typically a three-hour meeting followed by a two-hour lunch followed by three more hours of "deliberations". ${ }^{90}$ Thus, the entire process is often described as 'rubber-stamping by politicians', ${ }^{91}$ which causes a painful déjà vu feeling of the pre-Lisbon 'democracy deficit' debate.

The reference to the HR in terms of the policy formation process is not appropriate. Despite the fact that she is relatively often associated with policy formation, ${ }^{92}$ in reality she lacks both the formal competences and resources to be a substantial part of it, as the practical cases above have demonstrated. However, these associations emphasise the third consequence, which is the need for a clearer distinction between policy formation and implementation levels, both formally and institutionally. Moreover, this distinction will allow a specification of debate in terms of the EP's involvement at either level.

Answering the question in the title of this section, I argue here that CFSP parliamentarisation provides a complex solution to most of the problems mentioned. First of all, this development will enhance the EU unstable sui generis status. Being such an entity implies a difference from a state with all its established attributes of sovereignty, including international actorness. Therefore, legitimacy develops into an issue of major importance. ${ }^{93}$ Furthermore, actions establishing both its own EU-level obligations and obligations for its Member States require a strong source of direct legitimacy, at least comparable with national legislatures. Thus, the EP hardly has any alternative. It is the only parliament at the EU level, it is directly elected by the Union's citizens, ${ }^{94}$ it is the only institution able to ensure democratic control over other EU institutions as collective bodies, and its powers and practices are common to the Union as a whole. ${ }^{95}$

Letting the EP play a notable role within the CFSP will undermine the 'democracy deficit' debate both in its general and specific 'double deficit' formats. However, this approach implies the EP's involvement in the entire political cycle, which includes the preparation and formation

\footnotetext{
88 J Howorth, 'Decision-Making in Security and Defence Policy: Towards Supranational Intergovernmentalism?' (2011) KFG Working Paper Series, No 25, March 2011, 23 <www. polsoz.fu-berlin.de/en/v/transformeurope/publications/working_paper/index.html> accessed 30 December 2016.

89 ibid 7.

90 Arts 22(1), 26 TEU.

91 Howorth (n 88) 7.

92 Paul (n 41) 17.

93 Mittag and Wessels (n 57) 11.

94 Art 14 TEU.

95 Lord (n 61) 1143.
} 
of the CFSP as well as supervision over policy implementation. ${ }^{96} \mathrm{My} \mathrm{sec}$ ond argument is that the EP's participation will enhance the structure for the currently amorphous and tangled CFSP formation process, taking into consideration its huge experience of policy formation within other areas, ${ }^{97}$ as well as the importance of the institutionalised debate for the policy formation process.

The third argument is the influence of parliamentarisation on both European public opinion and partner countries. In this sense, the EP's role is diverse and multifaceted, ranging from provoking public resonance and mobilising public opinion ${ }^{98}$ to bridging between the CFSP and European public opinion in search of public support 'and popular commitment for the EU's global engagement'. ${ }^{99}$ From a more specific perspective, it should be stressed that foreign policy is now under increasing pressure for greater transparency from public opinion, which has become increasingly aware of the impact that international politics has on people's lives. ${ }^{100}$ Furthermore, this policy area still entails a high level of potential political risks, ${ }^{101}$ with the current refugee crisis being an illustration. Therefore, the issue of public support is a fundamental necessity. ${ }^{102}$ With the close link between public support, democratic legitimacy and the issue of accountability, ${ }^{103}$ the EP's involvement in the CFSP formation process looks expedient if the EU actions are to be accepted and supported by the citizens. ${ }^{104}$

In the wider context, elitism, over-bureaucracy, complexity and the inability to communicate results continue to be evident features of the European integration process in the public view. ${ }^{105}$ Against the background of Europeans losing their trust in the EU project, there is a growing need for the EP to enhance its role in regard to the CFSP with its 'double democratic deficit' problem and 'rubber-stamping by politicians' pattern of making decisions. Thus, from the theoretical perspective, the parliamentarisation of the CFSP is a rational process as it refers to arguments from the 'input legitimacy' debate. Therefore, it is able to enhance

\footnotetext{
96 Mittag and Wessels (n 57) 17.

97 Specifically stressing international trade, aid and development policies.

98 D Viola, European Foreign Policy and the European Parliament in the 1990s: An Investigation into the Role and Voting Behaviour of the European Parliament's Political Groups (Ashgate 2000) 177.

99 Gabriele Albertini, 'The Role of the European Parliament in the Common Foreign and Security Policy (2009) 5 The European - Security and Defence Union 8.

100 Thomas Nowotny, Diplomacy and Global Governance: The Diplomatic Service in an Age of Worldwide Interdependence (Transaction 2011) 155.

101 Lord (n 61)1138-1139.

102 Bajtay (n 15) 39.

${ }^{103}$ Mittag and Wessels (n 57) 1.

104 ibid.

105 Bajtay (n 15) 40.
} 
this policy area by embedding this theoretical background into the foundations of the political processes within the CFSP. By doing so, parliamentarisation will reinforce the internal political stability of the Union and place the EU into a wider pan-European political context.

\section{From theoretical to practical reasoning}

In addition to the theoretical reasoning delineated above, CFSP parliamentarisation has a number of practical benefits. This section submits that the formal connection of public political debate in the EP to the CFSP formation process will enhance its consistency, effectiveness and transparency, simultaneously contributing to the formation of genuinely common European policy, thus altering the current national-based mode. To some extent, this debate is a continuation of the legitimacy discourse, albeit from the perspective of 'output' legitimacy, which is associated mainly with institutional performance as well as with the success of particular policies.

The current CFSP rules do not prevent the EP from hearing any international topic due to the general 'power of debate' - something that the EP has been constantly doing since the famous case of the Spain Association Agreement of 1962. The most recent example of the continuation of this practice is the Ukrainian crisis, with the EP closely following the development of the situation. ${ }^{106}$ Thus, the EP has been instinctively doing something that is considered to be the major task of every parliamentary institution - debating policies. In this sense, the EP has developed an impressive arsenal of instruments, including both 'rhetorical actions'107 and traditional parliamentary tools. In particular, Stavridis has listed the following: foreign policy debates, declarations, reports and other rhetorical statements, hearings as well as resolutions and policy recommendations. ${ }^{108}$ This list can be extended to include rapporteurs, committees, (special) commissions of inquiry, oral and written questions ${ }^{109}$ and financial/budgetary control. ${ }^{110}$

However, the current 'special' CFSP rules formally exclude the EP both from the policy formation process and from participation in the con-

\footnotetext{
${ }^{106}$ From December 2013 until January 2015, the EP adopted 9 special resolutions on Ukraine.

${ }^{107}$ F Schimmelfennig, 'The Community Trap: Liberal Norms, Rhetorical Action, and the Eastern Enlargement of the European Union' (2001) 55(1) International Organization 48.

108 S Stavridis, "The CFSP/ESDP, Parliamentary Accountability, and the "Future of Europe" Convention debate' (2003) Working Paper no 42, Institut Universitari d'Estudis Europeus 3. ${ }^{109}$ Mittag and Wessels (n 57) 25.

${ }^{110} \mathrm{C}$ Gusy, 'Parliaments and the Executive: Old Control Rights and New Control Contexts in German' in Katja S Ziegler, Dennis Baranger and AW Bradley (eds), Constitutionalism and the Role of Parliaments (Hart Publishing 2007) 132.
} 
clusion of international agreements within this policy area. It is easier to begin with the latter as there is no valid argument for this status quo, except for the position of Member States, which are reluctant to create a powerful Brussels-based decision-making forum for foreign policy. ${ }^{111}$ However, reference to the 'sovereignty symbols' is not appropriate as it has been undermined by supranational integration in other 'symbolic' areas. ${ }^{112}$ Against the background of the EP's wide involvement in negotiations of international agreements in adjoining areas of foreign policy, the traditional arguments of the special nature of the CFSP is not really convincing. On the other hand, the benefits of the formal inclusion of the EP into the treaty-making procedure are similar to those for its participation in the policy formation process.

This section focuses on the potential benefits that parliamentarisation can bring to the CFSP and it provides three major practical arguments to support the idea for the EP's participation in the CFSP formation process, including its participation in the conclusion of international agreements. First, the EP is the only institution capable of being the forum for shaping common European policies, ensuring discussion of the entire spectrum of existing options and opinions. Further, the interconnection between parliamentary debate and policy formation has traditionally been viewed as a cornerstone of the process. ${ }^{113}$ Second, public debate in the EP is the only transparent way to set the CFSP priorities for the limited resources available. ${ }^{114}$ Third, parliamentary participation will ensure consistency of policies as well as control over the transformation of the treaty-based Union values to specific policies, thus ensuring the recognisability of EU foreign policy.

From the 1970s, the EP was increasingly operating as a parliamentary institution with the major objective of providing 'an arena in which every opinion can produce itself in full light to be tested in adverse controversy'. ${ }^{115}$ As a result of the enhancement of the EP's role in the EU institutional system, its function as a potential forum for debate and the launching of initiatives was emphasised, ${ }^{116}$ often with further

\footnotetext{
111 J Howorth, 'European Defence and the Changing Politics of the European Union: Hanging Together or Separately?' (2001) 39(4) Journal of Common Market Studies 765.

112 N Klein and W Wessels, 'CFSP Progress or Decline after Lisbon?' (2013) 18(4) European Foreign Affairs Review 449, 466.

${ }^{113}$ N Witzleb, A Martinez, and P. Winand (eds), The European Union and Global Engagement Institutions, Policies and Challenges (Edward Elgar 2015) 23-40; S Saurugger, Theoretical Approaches to European Integration (Palgrave Macmillan 2014) 304.

$114 \mathrm{~J}$ March and J Olsen, Democratic Governance (Free Press 1995).

115 John Stuart Mill, Utilitarianism. On Liberty and Considerations on Representative Government (first published 1861, Dent 1972) 239-240.

116 Corduneanu (n 42) 59.
} 
connection to the phenomenon of elite socialisation. ${ }^{117}$ Today, the provision of a 'grand forum' for the discussion of foreign policy is considered to be among the EP's principal functions. ${ }^{118}$ There is obviously a match between the pressing necessity of having political debate within a highly politicised area, which the CFSP is, ${ }^{119}$ and the traditional function of parliaments, which is to ensure that policies are discussed publicly and that reasons for the decision are provided to the public. ${ }^{120}$ In the EU, the necessity for debate over foreign policy is even higher than in a state, as, in addition to traditional general reasoning, the EU has three unique reasons of its own.

The common general reasons for such debate are rather straightforward and are based on the rationale of exposing and discussing diverse views on strategic direction and policy priorities, thus diminishing potential risks for erroneous decisions. ${ }^{121}$ Further, public parliamentary debate ensures discussion of the entire spectrum of available solutions. Specific EU reasons include: the need for CFSP compliance with declared values and principles, the need for the formation of all-European common approaches and the need to ensure the synergy of the CFSP with other areas of foreign policy. None of these tasks can realistically be achieved with the EP remaining formally excluded from the policy formation process.

The initial question for foreign policy formation implies the determination of values and identities it is intended to defend. ${ }^{122}$ In the case of the EU, these values are stipulated in the founding treaties, ${ }^{123}$ thus enjoying the highest normative power. However, the transformation of those values and principles into specific policies implies a certain degree of control over the policy-making process. This article supports the argument for the importance of public control over any exercise of political power in the context of collective choices of values. ${ }^{124}$ In this context, parliamentary procedures imply a higher level of scrutiny to secure the compliance of policies with the declared values. Furthermore, the EP's established reputation as 'the champion of European values' ${ }^{125}$ is a political guarantee for its value-based debate.

\footnotetext{
117 C Strøby-Jensen, 'Neo-functionalism' in Cini and Pérez-Solórzano Borragán (n 66) 75-77.

118 Geoffrey Edwards, The Pattern of the EU's Global Activity' in Christopher Hill and Michael Smith (eds), International Relations and the European Union (OUP 2011) 57.

119 Bajtay (n 15) 39.

${ }^{120}$ A Benz, 'Path-Dependent Institutions and Strategic Veto Players: National Parliaments in the European Union' (2004) 25(5) West European Politics 875.

${ }^{121}$ Bajtay (n 15) 39.

${ }^{122}$ O Waever, 'European Security Identities' (1996) 34(1) Journal of Common Market Studies 103.

${ }^{123}$ Art 21 TEU.

${ }^{124}$ Lord (n 61) 1136-1137

${ }^{125}$ 'The European Parliament as a champion of European values' (2008) Office for Official Publications of the European Communities.
} 
Against the divergence among the Member States on foreign policy issues, the need for the formation of shared aims is another fundamental challenge for the EU. Scholars stress the initial steps in the slow and painful process of their generation. ${ }^{126}$ From this perspective, the existence of a 'grand forum' for the search for and debate on such common grounds is vital. Moreover, the formal connection of parliamentary debate to policy formation is likely to foster the process, as this will alter its mode from its current intergovernmental setting. Thus, decisions must be based on common European interests, implying that these interests have been previously identified, debated and consolidated. In this sense, the EP's role in consensus building is supported by the legitimacy argument. In turn, the consensus building process can be a solid basis for long-term strategic guidelines, which are necessary to enhance the consistency of EU foreign policy.

Perhaps, the last point to make is the need for "cross-pillar" interactions', ${ }^{127}$ or the development of synergy between the CFSP and other segments of foreign policy. Here, the EP is also in a unique position as it is already a part of the policy formation process for trade, aid and development. Moreover, for decades it has been playing a significant role in terms of democratisation and human rights protection. Thus, the EP's exclusion from the CFSP process remains illogical. In academic debate the idea of 'upgrading' the EP's role to that of an active participant in the CFSP decision-making process has already been discussed as being the simplest option to reduce the inconsistency of the Union's institutional design'. ${ }^{128}$ From the institutional perspective, the establishment of parity for the EP's competences throughout all foreign policy areas will result in practical rationality benefits, including the unification of rules and procedures, as well as the simplification and harmonisation of the EU institutional system, leading to the reduction of transaction costs, which is often identified as a factor of institutional development. ${ }^{129}$

\section{Scrutinising the EU executives}

Parliamentary control over policy implementation is the last (but not the least) stage of the political cycle in terms of democratic accountability. ${ }^{130}$ In this sense, the EP's role can hardly be over-estimated in terms

\footnotetext{
${ }^{126}$ U Guérot, 'Germany Goes Global: Farewell Europe' (European Council on Foreign Relations, 16 September 2010) <http://ecfr.eu/content/entry/commentary_germany_goes_ global/> accessed 30 December 2016.

127 Wouters and Raube (n 1) 18.

128 Mittag and Wessels (n 57) 26.

$129 \mathrm{~J}$ Stacey and B Rittberger, 'Dynamics of Formal and Informal Institutional Change in the EU’ (2003) 10(6) Journal of European Public Policy 858, 866.

${ }^{130} \mathrm{H}$ Hänggi and H Born 'Governing the Use of Force Under International Auspices: Deficits in Parliamentary Accountability’ SIPRI Yearbook (OUP 2005) 201.
} 
of making EU executives provide sufficient information and justify their actions. ${ }^{131}$ It is necessary to stress that post-Lisbon practice has made considerable progress along this path, ensuring the EP's involvement to a much greater degree than the founding treaties stipulated. However, in order to develop into a stable functioning system, these practices require formalisation with a further connection to the EP's formal competence to sanction executives.

It should be noted that EU informal practices have traditionally aimed at diminishing tension and inter-organisational conflicts. ${ }^{132}$ They are based on, rather than constrained by, the founding treaties and usually go much further than treaty-based limits. Their scope includes interinstitutional agreements, ${ }^{133}$ informal commitments and numerous written and unwritten rules. In this way, the post-Lisbon inter-institutional dynamics strengthened the influence of the EP, which enhanced its scrutinising position regarding all three major elements of the post-Lisbon system of the CFSP - the HR, the EEAS and the Union's delegations. ${ }^{134}$

The EP's relations with the HR are now based on the new InterInstitutional agreement of $2013^{135}$ and traditional informal commitments practice. Moreover, the practice of inauguration Commission commitments was extended to the HR. ${ }^{136}$ Together with a number of other similar documents, ${ }^{137}$ these commitments ensured substantially deeper EP cooperation with the HR than the Lisbon Treaty required. Furthermore, the HR volunteered for 'special relations' with the EP, emphasising its democratic legitimacy, and understanding the importance of parliamentary accountability. ${ }^{138}$

To some extent, the HR was driven by institutional reasons aiming at enhancing her current uncertain position. ${ }^{139}$ In this sense, the article re-

\footnotetext{
${ }^{131}$ D Curtin, P Mair and Y Papadopoulos. 'Positioning Accountability in European Governance: An Introduction'. (2010) 33(5) West European Politics 929, 937

$132 \mathrm{~J}$ Stacey, Integrating Europe: Informal Politics and Institutional Change (OUP 2010) 68.

${ }_{133}$ O Moskalenko, 'Role of Inter-institutional Agreements in the Rise of European Parliament Competences External Relations' (2014) 67(1) Studia Diplomatica - Brussels Journal of International Relations 15.

${ }^{134}$ S Duke, 'The Lisbon Treaty and External Relations' (2008) 1 Eipascope 13 <www.eipa. eu> accessed 30 December 2016.

135 See n 33.

${ }^{136}$ Hearing with Baroness Ashton at the Committee on Foreign Affairs (6 January 2010). Parliament hearing of Mrs. Mogherini (6 October 2014).

${ }^{137}$ High Representative Declaration on Political Accountability (8 July 2010); High Representative Statement on the basic organization of the EEAS central administration (8 July 2010).

${ }^{138}$ K Raube, 'The Emerging Relationship between the European Parliament, the High Representative and the External Action Service' (2011) Working Paper No 74, $9<\mathrm{https}$ ://ghum. kuleuven.be/ggs/publications/working_papers/new_series/wp71-80/wp74.pdf> accessed 30 December 2016.

139 J-C Piris, The Constitution for Europe: A Legal Analysis (CUP 2006) 154.
} 
fers to the institutional approach, using its argument of maximisation of one's own self-interests and preferences, ${ }^{140}$ as CFSP parliamentarisation has the potential to reinforce the HR's institutional role at the implementation level, ${ }^{141}$ since reference to policies and programmes legitimated by the EP's participation will certainly add to the political weight of his/ her actions. Thus, the HR's status of primus inter pares in his/her relations with the 'Group of External Relations Commissioners' will acquire a different meaning, as the implementation process would imply common responsibility instead of the current dependence of the HR on the commissioners involved. ${ }^{142}$

In its relations with the EEAS, which is often viewed as the cornerstone of the post-Lisbon architecture of external relations, ${ }^{143}$ the EP used its budgetary leverage to ensure the accountability of the service. It managed to establish a structured relationship with the EEAS in terms of political control, supervision and budgetary oversight. ${ }^{144}$ Furthermore, the EP strengthened its influence after the EEAS reform of $2013,{ }^{145}$ thus going much further than the Treaties suggested. ${ }^{146}$

The EP also made some steps towards ensuring its scrutiny over the EU delegations. As the US experience shows, diplomatic personnel can be held directly accountable; however, the Lisbon Treaty has not provided for any special procedure in this sense. ${ }^{147}$ Nonetheless, the EP developed a rule to have heads of the delegations appear before the EP prior to the start of their mission. ${ }^{148}$ This unofficial rule was formalised by the Rules of Procedure, ${ }^{149}$ often seen as a specific channel to reinforce the EP's competences for CFSP matters. ${ }^{150}$ However, the attempt to develop this practice into full-scale US Congress-style hearings failed. ${ }^{151}$ Frequently, reference is made to the EP's lack of formal competence to

\footnotetext{
140 B Rosamond, 'New Theories of European Integration' in Cini and Pérez-Solórzano Borragán (n 66) 116.

141 Art 22 (1) TEU.

142 Paul (n 41) 29.

${ }^{143}$ Raube (n 138) 3.

144 ibid 11.

${ }^{145}$ D Fiott, 'The Diplomatic Role of the European Parliament's Parliamentary Groups' (2015) 3epa SIEPS European Policy Analysis 8-9 <http://papers.ssrn.com/sol3/papers. cfm?abstract_id=2578868> accessed 30 December 2016.

146 E Wisniewski, 'The Influence of the European Parliament on the European External Action Service' (2013) 18(1) European Foreign Affairs Review 100.

147 Raube (n 138) 13.

148 Fiott (145) 8-9.

149 Rules 93, 95 EP Rules of Procedure (2011).

${ }^{150}$ L Rumrich 'The CFSP within the Institutional Architecture: The Role of the European Parliament' (2006) 2(2) Hans Law Review 211, 215.

${ }^{151}$ B van Vooren, 'A Legal-Institutional Perspective on the European External Action Service' (2010) CLEER Working Papers No 7, 30.
} 
block the appointment of a head of a delegation. ${ }^{152}$ Nonetheless, in this case political consequences may suffice as it will be rather embarrassing to have somebody leading an EU delegation after a negative opinion from the EP.

In addition to the special mechanisms mentioned above, the EP can certainly use its traditional instruments of scrutiny, such as special committees, rapporteurs and questions, as well as special hearings, workshops, ad hoc missions, etc, ${ }^{153}$ which already place the EP in a strong position in terms of scrutinising CFSP executives. Against the background of the well-developed informal but rather efficient system of EP scrutiny over all CFSP major segments, the question is why these practices need formalisation. In general terms, the 'power to sanction' has traditionally been part of parliamentary control, ${ }^{154}$ thus making national parliaments decisive actors in co-determining final policy outputs. ${ }^{155}$ From a more practical perspective, there are two basic answers to this question. The first is the fact that the EP should not expect too much from informal and indirect power'. ${ }^{156}$ This submission echoes the claim for strengthening the EP's formal rather than informal rights, as expressed in a number of previous studies. ${ }^{157}$ The practical rationale of this argument lies in the need to establish a systematic and institutionalised structure of interaction, which requires the EP's right 'to be heard' to be assured, as this right is of vital importance for the effectiveness of parliamentary supervision. ${ }^{158}$ Thus, the establishment of a stable basis requires its formalisation by legal means.

The second argument stresses the importance of formal leverage in the EP's relations with the EU executives. With reference to the experience of the EP's consent right for international agreements, it is necessary to stress that after two landmark 'no-consent' votes, ${ }^{159}$ the EP used this leverage to guarantee a sufficient level of cooperation throughout the negotiation process instead of following the traditional parliamentary voting pattern. In other words, the formal leverage of possible sanctions would foster the development of mutually acceptable inter-institutional practices without limiting the scope of parliamentary scrutiny.

\footnotetext{
152 Raube (n 138) 6.

${ }^{153}$ Bajtay (n 15) 31.

${ }^{154}$ C Caballero-Bourdot, 'Inter-parliamentary Scrutiny of the CFSP: Avenues for the Future (2011) Occasional Paper, no 94, Institute for Security Studies, 13.

155 Wouters and Raube (n 1) 4.

${ }^{156}$ Lalone (n 69) 14.

157 Mittag and Wessels (n 57) 25.

158 Raube (n 138) 4.

159 The Cases of the EU-USA SWIFT Bank Data Transfer Agreement (SWIFT) and the AntiCounterfeiting Trade Agreement (ACTA).
} 


\section{Conclusions}

Post-Lisbon practice has revealed that the limited format of the EP's involvement constrains the development of the CFSP. Furthermore, the current formal intergovernmental set-up for the CFSP is often recognised as an obstacle in the way of synergy within EU foreign policy. Against the background of the current problematic development of EU external relations, the paper has studied the idea of the parliamentarisation of the CFSP from different perspectives. Although the reasoning differs, the conclusions are identical - parliamentarisation of this policy area is a rational choice, providing a practical and comprehensive solution to a number of diverse problems currently existing for EU external relations.

From a theoretical perspective, this process successfully meets the need for more democracy for the EU, both in a wider context and within the specific area of foreign policy (input legitimacy). In the practical sense, it will ensure a forum for public policy debate, thus enhancing the transparency, coherence and effectiveness of the policy formation process (output legitimacy). Separately, one should stress the potential of parliamentarisation for meeting specific EU needs, which are: the formation of a genuinely common European CFSP, a value-based policy formation process, and the development of synergy between the CFSP and other areas of foreign policy.

The increased level of parliamentary scrutiny over the implementation stage will ensure an enhanced level of EU executives' accountability through instruments of parliamentary control. From the institutional perspective, CFSP parliamentarisation will contribute to the harmonisation of the EU institutional system through the unification of the EP's status and competences throughout all areas of foreign policy and by reinforcing the HR's currently uncertain status in terms of the policy implementation process. 